\title{
Løbende nationale reproduktionsregistre og ad hoc data
}

\author{
Jørn Olsen \\ Klinisk Epidemiologisk Afdeling, Aarhus Universitetshospital, DK-8200 Aarhus N, Danmark \\ jo@ph.au.dk
}

\section{ENGLISH SUMMARY}

Olsen J. National registration in human reproduction and research oriented ad hoc data. Nor J Epidemiol 2017; 27 (1-2): 27-31.

The Nordic countries have a long tradition for collecting and storing of data in reproductive health. These registers cover the entire population and focus on health outcomes. They have gradually been made available for research and if supplemented with data on potential risk factors in reproductive health, they provide a strong basis for research in potential causes of disease in the reproductive system. Several pregnany/birth cohorts have been successful in providing important information in preventive medicine. The most important of these are the Norwegian birth cohort (MoBa) and the Danish National Birth Cohort (DNBC). Both include about 100,000 newborns. They are based on the rationale that many diseases have causes that start operating in fetal life - fetal programming of diseases - even diseases that manifest themselves later in life (adult diseases). Examples of historic and more recent findings are presented in the following text.

Risk of disclosure of personal data is of concern. We have not had examples of such unwanted disclosure and we want to keep this achievement. We clearly have to do many things different and better in the future. Fortunately, technical solutions are available and promising.

The registers and the ad hoc data sources have given the Nordic epidemiologists a leading position in reproductive health. To keep that position, we need to plan new cohorts and train more people. If we do that we will be able to continue our collaboration with colleagues all over the world.

This is an open access article distributed under the Creative Commons Attribution Licence, which permits unrestricted use, distribution, and reproduction in any medium, provided the original work is properly cited.

\section{INTRODUKTION}

Ethvert samfund vil indsamle data om fødsler og de nyfødtes helbred. Disse data er ofte komplette - eller næsten komplette - og omfatter befolkningen som helhed. I de nordiske lande (og i andre lande) har disse registre været af stor betydning for den perinatale forskning, især fordi offentlige registre kan kobles med andre befolkningsregistre og dermed øge den informationsmængde, der har forskningsmæssig betydning. De fleste oplysninger vedrører sygelighed og i mindre grad prædiktorer for sygdom. Til brug for forskning $\mathrm{i}$ den præventive medicin savner man oplysninger om mulige årsager til sygdomme. I de nordiske lande vil der ofte indsamles data om borgernes erhverv, sociale kår, medicinforbrug, miljø (f.eks. via geokoder) og enkelte andre forhold.

For at få et bedre udbytte af helbredsdata til gavn for sygdomsforebyggelsen i befolkningen blev det tiltagende klart, at der skulle indsamles data i større skala om mulige årsager til sygdomme. Disse data skal kobles med helbredsdata for at give ny information om sygdomsårsager og betydningen af behandlinger og sygdomsforebyggende aktiviteter. Hermed skabtes ideen om at etablere en stor graviditetskorhorte og denne ide fik støtte fra mange forskellige kilder og modstand fra næsten lige så mange. Dels havde der været flere mindre graviditets-/fødselskohorter i alle de nordiske lande, og der var "The National Collaborative Perinatal Study" fra 1950erne - dataindsamling startede i 1958 (1). Formålet i denne kohorte var meget speci- fikt at finde årsagerne til cerebral parese (CP), som man troede var forårsaget af fødselskomplikationer. Dette synspunkt blev fremført af William Little men blev allerede på det tidspunkt tilskrevet føtale programmeringsmekanismer af Sigmund Freud. De frygtede ikke klodsede titler - kohorten hed i begyndelsen "The Collaborative Investigation on the Clinico-Pathologic Correlation in Cerebral Palsy, Mental Retardation, and other Neurological Disorders having their Origin in the Perinatal Period".

Der var også fortsat stor interesse for at finde infektiøse årsager i graviditet til helbredsproblemer for barnet. TORCH var det begreb der opsummerede en transgenerationel effekt af toxoplasmose, rubella, cytomagalovirus og herpes. O står for "other" - $\mathrm{i}$ troen på at der måtte være andre mikrobiologiske årsager til overført sygdom fra moder til foster og Zika virus har fyldt den ene plads ud, men der er rum til flere og der er behov for flere studier om betydningen af infektionssygdomme under graviditet.

Fra samme tidsperiode kom studiet om vaginal cancer $i$ en alder, hvor man stort set ikke tidligere havde set denne cancer. Unge kvinder fik vaginal cancer med større hyppighed, hvis deres mødre havde fået et kraftigt østrogenpræparat (DES) under graviditeten for at mindske risikoen for spontan abort (2).

Tiden var derfor moden til en større satsning på at belyse betydningen af graviditetsperioden for fosterets udvikling - eller det begreb, der blev betegnet 'føtal programmering' (3-6). De teknologiske muligheder var til stede, og der var en voksende gruppe af epidemio- 
loger, der kunne analysere store datamængder på kort tid og de nationale statistiske bureauer blev mere villige til at åbne deres registre for forskningsmæssige formål, hvilket var af stor betydning for vore muligheder for at forbedre især den forebyggende medicin.

I USA planlagde man "The National Children's Study" med 100.000 børn som skulle være repræsentative for hele landets nyfødte i en periode. I England havde man gennemført Avon Longitudinal Study of Parents and Children (ALSPAC) (7) - en kohorte med 15.000 deltagere og en meget intensiv og tæt longitudinel dataindsamling. Som ved etablering af the Collaborative Perinatal Study diskuterede man sample size, om det skulle være en repræsentativ stikprøve, og om det skulle være et studie baseret på eksisterende protokoller. Al erfaring siger, at sample size er vigtigst og disse studier skal være så store som muligt.

Vor oprindelige ide i den danske gruppe var at starte kohortestudier i alle de nordiske lande med 100.000 deltagende nyfødte børn fra hhv. Danmark, Norge, Finland og Sverige samt 50.000 fra Island. Den daværende danske medicinaldirektør Palle Juul Jensen støttede denne ide og bragte det op på et møde i Nyborg (Hesselet) med de nordiske medicinaldirektører og planlægningen blev fulgt op med andre møder. Det endte med at kun Danmark og Norge gik i gang med at forberede et sådant projekt - hhv. MorBarn (MOBA) i Norge og the Danish National Birth Cohort (DNBC). I Danmark havde man en større 10-årig bevilling fra Grundforskningsfonden i ryggen og i Norge var Folkehelseinstituttet den vigtigste økonomiske støtte, men der kom også midler fra NIH, NIEH og andre fonde.

Forsdals iagttagelser fra Norge viste, at middelalderlige mænds risiko for at dø korrelerede med børnedødeligheden i de geografiske områder de blev født $\mathrm{i}$ (8). Og Barkers påvisning af, at denne effekt blev medieret af fotal vækstreduktion, var af stor betydning for at opnå fondsstøtte. Med denne lange induktion og latenstid fra påvirkning til helbredseffekt var det klart at disse kohorter skulle følges over lange tidsperioder og fra konception til død blev målsætningen. Der skulle derfor sikres en langsigtet strategi for administration, økonomisk styring og datasikkerhed.

\section{FORSKNINGSRESULTATER AF STOR BETYDNING PÅ DEN TID}

Barkers model for føtal programmering var en simpel model hvor føtal vækst kunne hæmmes ved utilstrækkelig maternal ernæring, udsættelse for maternal stress eller en dårligt fungerende placenta. Denne føtale væksthæmning kunne føre til det metabolistiske syndrom med senere øget risiko for fedme, diabetes og tidlig aldring. Modellen blev senere videreudviklet af Gluckman og Hanson $(9,10)$ og kom blandt andet til også at omfatte epigenetiske mekanismer og genekspression.

Dyreeksperimentielle undersøgelser på mus havde vist, at manipulation med kostfaktorer inden for rammerne af et tilstrækkeligt kalorieindtag korrelerede med disse mus' levetider med en mulig effekt på op til $25 \%$ længere levetid med en lødig kost versus en fastfood-lignende, men kaloriesufficient kost (11). Vi har ikke set noget så markant for mennesker, men det kan selvfølgelig skyldes, at vi ikke har de nødvendige data med tilstrækkelig follow up-tid endnu.

Udsættelse for svær stress under graviditet er associeret med visse medfødte misdannelser og også andre lidelser. Vi har data fra en række 'bereavement' studier $(12,13)$, og vi har data fra sultkatastrofen i Kina (14) og i Rotterdam under Anden Verdenskrig (15). Disse studier støttede ideen om føtal programmering hvor den tidlige udsættelse for alvorlig sult undertiden kan føre til kroniske lidelser, som først viser sig meget senere i livet, f.eks. skizofreni. Om den sygdomsfremkaldende påvirkning er sult, stress eller toksiske er dog fortsat uklart. Manglen på mad er en alvorlig stressfaktor og kan føre til at alt, hvad der ligner mad, spises.

Der er sikkert sygdomme, tilstande der har en ætiologi, der starter i fosterlivet. Fører disse eksponeringer til 'føtal programmering' må vi studere om der er faktorer, der fører til føtal de-programmering. Visse kostfaktorer, vitaminer og mineraler har måske en sådan virkning $(16,17)$.

\section{NYE FORSKNINGOMRÅDER}

Vi har set en dramatisk udvikling i befolkningsreproduktionsmønstre. Forældre er ofte ældre, når de får børn. Flere føder efter ART (artificial reproduktive therapy) og familiemønstre ændrer sig også på anden vis. Hvad betyder disse demografiske ændringer for børnenes helbred på kort og langt sigt?

Kroniske sygdomme kan undertiden ændre det intrauterine miljø og det kan måske have føtal programmeringseffekt. Vi ved at kvinder med en dårligt reguleret diabetes ikke alene føder større børn, men også får børn med en øget risiko for medfødte misdannelser (18). Thyroide sygdomme synes også at have programmeringseffekt, især på psykiske sygdomme. Det samme gælder visse immunsygdomme og sikkert også mange andre sygdomme. Vi har kun få studier med tilstrækkelig lang follow-up tid.

Ved at bruge eksisterende data om drikkevands indhold af lithium og demensforekomst ses en beskyttende effekt af et højt lithiumindhold på demenshyppighed (19). Hvis denne sammenhæng har ætiologisk betydning er den relevante eksponering måske i fosterlivet og man bør undersøge ikke alene relationen til demens, men også til en række andre sygdomme og færdigheder.

Medicin bruges ofte til gravide, men uden den sikkerhed, der er en del af de godkendelsesprocedurer, der forudsætter afprøving blandt mennesker inden markedsføring - blot ikke gravide kvinder og børn. Medicin bruges alligevel til gravide kvinder, dels fordi det er nødvendigt $\mathrm{i}$ visse situationer, dels fordi graviditeten ofte ikke er erkendt tidligt i forløbet.

Siden Thalidomid-katastrofen i 1960erne (20) har man været opmærksom på den særlige risiko gravide 
kvinder løber, når de bruger visse typer af medicin. Næsten al opmærksomhed har været rettet mod medfødte misdannelser, selv om funktionelle defekter er meget hyppigere. Der er næppe tvivl om at vi bør undersøge mange flere præparater for føtal programmeringseffekt - ikke blot medfødte misdannelser. Erfaring fra studier af paracetamol (21-25) viser, at vi også skal interessere os for helt andre udfald. Dette præparat anses af mange for sikkert at bruge - også for gravide - men det er måske ikke rigtigt. Det er ikke sikkert at vi har studeret de relevante udfald.

Det var meget omdiskuteret i perioden før kohorten startede, om vi var vidne til en markant nedsættelse af sædkvaliteten blandt mænd i en række lande - ikke mindst Danmark. Især en publikation i BMJ (26) gav anledning til denne frygt. Man kunne få det indtryk at sædkvaliteten var faldet til næsten det halve over få årtier, og den sidste levedygtige sædcelle ville forlade klodens overflade efter et begrænset antal år. Det inspirerede P. D. James til at skrive bogen "The children of men" der blev til en film af samme navn. Hvis dette er en reel fare bør man især søge årsagerne tidligt i livet. Sædproduktion styres af Sertoliceller, der dannes $\mathrm{i}$ graviditeten og de tidlige barneår. Vi kendte til 1,2-Dibromo-3-chloropropane (DBCP), der ødelagde sædproduktion blandt nogle højt eksponerede voksne, men vi kender ikke meget til betydningen af de føtale eksponeringer på sædproduktion. Her er der et forskningsbehov, der skal dækkes. En ny undersøgelse viser fortsat fald i sædkvalitet op til vor tid (27), men data er fortsat for dårlige til egentlige konklusioner. Også de nye studier gentager mange af de problemer der var $\mathrm{i}$ BMJ-artiklen, selektionsbias, misspecifikation af studiepopulation, ukontrolleret confounding etc.

\section{ETISKE INDVENDINGER}

Der var enighed fra starten om det rigtige og vigtige $\mathrm{i}$ at have biologisk materiale med i kohorten fordi biologisk materiale giver mulighed for at belyse en række toksikologiske og genetiske hypoteser. I Danmark blev samtlige amter enige om at de ville finansiere denne biologiske dataindsamling gennem de praktiserende læger med en standard takst for at tage en blodprøve, som var beskeden. Næsten halvdelen af de praktiserende læger sagde nej til at deltage af økonomiske - og andre - grunde. De deltagende praktiserende læger skulle også udlevere projektets informationsfolder med den skriftlige samtykkeerklæring. Ca. 60\% af de inviterede kvinder sagde ja til invitationen og langt de fleste er fortsat med i BSMB. MoBA valgte rekruttering ved de rutinemæssige ultralydsskanninger i 2. trimester.

De reelle etiske indvendinger mod en dataindsamling af denne størrelse handler historisk om politisk misbrug af data for at forfølge folk med særlig holdninger eller karakteristika. Der er også helt aktuelle eksempler på et sådant politisk misbrug mange steder $\mathrm{i}$ verden. Vores egne brud på ret til et privatliv i Danmark skete for jøder og kommunister for mere end 60 år siden, men den aktuelle politiske retorik bringer måske også datasikkerheden for andre befolkningsgrupper i farezonen.

Mere eller mindre vidtløftige etiske overvejelser blev bragt frem i planlægningen af kohorten, som forsinkede og fordyrerede hele dataindsamlingsproceduren, der i øvrigt gik godt, da den først kom i gang. Vor dataindsamling førte ikke til store byrder for almen praksis og de deltagende læger var meget trofaste støtter i undersøgelsen. Jordmoderforeningen i Danmark havde taget skrapt afstand fra projektet og meget få jordmødre bidrog til dataindsamlingen. Flere jordmødre har senere bidraget med vigtige dele af projektets opfølgning og analyse.

Mange andre etiske problemer blev diskuteret, men hvad der står tilbage af etiske problemer er især eksistensen af disse data og ikke deres brug, som helt entydigt har været til befolkningens bedste. Eksistensen af data giver risiko for utilsigtede udslip af data, eller at nogen kan få adgang til personlige data, der kan bruges imod navngivne individer i f.eks. forsikringssager.

Selvom vi ikke har set eksempler på et sådant misbrug er det vigtigt hele tiden at forbedre datasikkerheden, og det betyder nye investeringer i datasikkerhed. Måske bør vi simpelthen kun opbevare og analysere data på det meste sikre edb-system, som måske findes i de statistiske centralbureauer.

Det er paradoksalt, at en type forskning næsten uden skadevirkninger, er udsat for en intens etisk bekymring. Der er ingen empiriske dokumentation for denne bekymring $i$ vor del af verden. Tværtimod giver disse data befolkningen mange muligheder for at holde kontrol med magthavere; er nye medicinske procedurer sikrere end dem de erstatter?; er nye kemiske komponenter vi udleder til naturen skadelige for mennesker?; hvilke levevaner har de største helbredsproblemer? etc. Alt sammen information, der er til gavn for befolkningen og hvis vi ikke bruger disse data til at belyse sådanne problemstillinger, så bør vi skrotte dem. Eksistensen af data kan potentielt føre til etiske problemer. Det er eksistensen af data, der kan være bekymrende - ikke deres brug. Derfor er det uetisk at begrænse brugen samtidigt med at man fastholder alle databaser. Og i visse lande er det givetvis fornuftigt at have så få databaser som muligt.

\section{AKTUEL Status}

Det er lykkedes at skaffe midler til en fortløbende dataindsamling i begge kohorter. Begge har en levende hjemmeside (www.dnbc.dk og www.fhi.no/studier/moba/) med opdaterede oplysninger om nye dataindsamlinger og nye publikationer. Begge kohorter er internationalt velkendte og har været med til at styrke det internationale samarbejde i nordisk epidemiologi og har skaffet betydelige udenlandske midler til forskningen. Begge databaser indgår $i$ en lang række nationale og internationale projekter. DNBC har 18-21 års follow-up tid og er klar til at inkorporere den næste generation, derfor den nye danske titel: "Bedre sundhed i generationer". 


\section{AfSLUTNing}

Ideen med at indsamle epidemiologiske data, der kan supplere de rutinemæssigt indsamlede helbredsdata til forskningsbrug, er god - også nu og i fremtiden. Man bør gentage denne dataindsamling vi startede for næsten 20 år siden hvert 25 . år - lidt over 400.000 ville så være i denne ad hoc nordiske kohorte. Gør vi det, vil vi permanent have en longitudinal dataindsamling, der dækker hele livsfasen fra konception til død og i de vekslende tidsperioder og geografiske områder i Norden.

Det er også vigtigt fortsat at sikre samarbejde mellem de største epidemiologiske forskningsmiljøer i landet for at sikre den bedste udnyttelse af data. Det er vigtigt at sikre en international deltagelse i denne forskning. Databasen skal forblive åben med adgang for andre til at efterprøve resultater og starte nye analyser.

Ikke alle, men nogle sygdomme bør studeres over lange tidsperioder. De udvikles i trin, der kan have vekslende ætiologi og de kan formentlig forebygges med forskellige midler i disse trin. Vor nye voksende viden om medieringsanalyser vil være vigtig nu og $\mathrm{i}$ fremtiden.

De nordiske lande finansierer en omfattende og vigtig administrativ dataindsamling. Indsamling af ad hoc data om mulige sygdomsfremkaldende forhold er med til at øge disse datas forskningsmæssige værdi til gavn for befolkningen og det vil være en beskedne økonomisk investering i forhold til udbyttet.

\section{KONKLUSION}

Kombinationen af landsdækkende administrative data med fokus på sygdom og død, samt ad hoc registre indhentet efter informeret samtykke og med detaljerede oplysninger om mulige årsager til sygdomme og funktionstab giver en god og særdeles produktiv forskningsplatform.

De administrative data giver mulighed for analyser uden selektionsbias og ad hoc datasamlingen giver ofte mange flere muligheder for confounderkontrol. Ved at bruge det overlap, der er mellem de administrative data og ad hoc data kan fordele ved begge datasamlinger udnyttes til at opnå resultater med god troværdighed. Det er vigtigt at disse datasamlinger suppleres med biologisk materiale af god kvalitet og i så stor mængde som muligt.

Det er af helt afgørende betydning at disse datasamlinger står til rådighed for alle forskere med gode projekter. Adgang til data må sikres med en uafhængig komité. Forskningsresultater skal formidles primært i videnskabelige tidsskrifter og til befolkningen, når de når et vist troværdighedsniveau. Præmatur formidling vil blot skabe usikkerhed og ofte unødvendig uro.

Det er besværligt og tidskrævende at indsamle og vedligeholde store datasamlinger og derfor må man sikre, at de personer, der påtager sig denne rolle også får gavn af denne indsats. Alle professionelle epidemiologer bør deltage aktivt $i$ dataindsamling $i$ det mindste $i$ en periode af deres uddannelse.

Datasamlingerne skal behandles med respekt for deltagernes personlige oplysninger. De skal opbevares centralt - gerne kun et sted - og brug af data skal overvåges. Vi skal ikke sprede sensitive data til lokale forskningscentre. Kontrolleret åben og sikker adgang til de mest opdaterede og fejlrettede data er det der giver de mest pålidelige og mest lovende forskningsresultater.

\section{REFERENCER}

1. Klebanoff MA. The Collaborative Perinatal Project: a 50-year retrospective. Paediatr Perinat Epidemiol 2009; 23 (1): 2-8.

2. Herbst, AL, Ulfelder H, Poskanzer DC. Adenocarcinoma of the vagina. Association of maternal stilbestrol therapy with tumor appearance in young women. $N$ Engl J Med 1971; 284 (15): 878-881.

3. Godfrey KM, Barker DJ. Fetal programming and adult health. Public Health Nutr 2001; 4 (2B): 611-24.

4. Barker DJP. Fetal origins of cardiovascular disease. Ann Med 1999; 31 (sup1): 3-6.

5. Barker DJ. Fetal origins of coronary heart disease. BMJ 1995; 311 (6998): 171-4.

6. Godfrey KM, Barker DJ. Fetal nutrition and adult disease. Am J Clin Nutr 2000; 71 (5 Suppl): 1344S-52S.

7. Niarchou M, Zammit S, Lewis G. The Avon Longitudinal Study of Parents and Children (ALSPAC) birth cohort as a resource for studying psychopathology in childhood and adolescence: a summary of findings for depression and psychosis. Soc Psychiatry Psychiatr Epidemiol 2015; 50 (7): 1017-27.

8. Forsdahl A. Observations throwing light on the high mortality in the county of Finnmark. Is the high mortality today a late effect of very poor living conditions in childhood and adolescence? 1973. Int J Epidemiol 2002; 31 (2): 302-8.

9. Gluckman PD, Hanson MA. The developmental origins of the metabolic syndrome. Trends Endocrinol Metab 2004; 15 (4): 183-7.

10. Gluckman PD, Hanson MA. Maternal constraint of fetal growth and its consequences. Semin Fetal Neonatal Med 2004; 9 (5): 419-25.

11. Ozanne SE, Hales CN. Lifespan: catch-up growth and obesity in male mice. Nature 2004; 427 (6973): 411-2.

12. Li J, Hansen D, Mortensen PB, Olsen J. Myocardial infarction in parents who lost a child: a nationwide prospective cohort study in Denmark. Circulation 2002; 106 (13): 1634-9. 
13. Li J, Johansen C, Hansen D, Olsen J. Cancer incidence in parents who lost a child: a nationwide study in Denmark. Cancer 2002; 95 (10): 2237-42.

14. St Clair D, Xu M, Wang P, Yu Y, Fang Y, Zhang F, Zheng X, Gu N, Feng G, Sham P, He L. Rates of adult schizophrenia following prenatal exposure to the Chinese famine of 1959-1961. JAMA 2005; 294 (5): $557-62$.

15. Lumey LH, Stein AD, Kahn HS, van der Pal-de Bruin KM, Blauw GJ, Zybert PA, Susser ES. Cohort profile: the Dutch Hunger Winter families study. Int J Epidemiol 2007; 36 (6): 1196-204.

16. Bisgaard H, Stokholm J, Chawes BL, Vissing NH, Bjarnadóttir E, Schoos AM, Wolsk HM, Pedersen TM, Vinding RK, Thorsteinsdóttir S, Følsgaard NV, Fink NR, Thorsen J, Pedersen AG, Waage J, Rasmussen MA, Stark KD, Olsen SF, Bønnelykke K. Fish oil-derived fatty acids in pregnancy and wheeze and asthma in offspring. N Engl J Med 2016; 375 (26): 2530-9.

17. McGrath JJ, Berk M. Could lithium in drinking water reduce the incidence of dementia? JAMA Psychiatry 2017 Aug 23 [Epub ahead of print].

18. Parnell AS, Correa A, Reece EA. Pre-pregnancy obesity as a modifier of gestational diabetes and birth defects associations: a systematic review. Matern Child Health J 2017; 21 (5): 1105-1120.

19. Kessing LV, Gerds TA, Knudsen NN, Jørgensen LF, Kristiansen SM, Voutchkova D, Ernstsen V, Schullehner J, Hansen B, Andersen PK, Ersbøll AK. Association of lithium in drinking water with the incidence of dementia. JAMA Psychiatry 2017 Aug 23 [Epub ahead of print].

20. McBride: Thalidomide and congenital abnormalities. Lancet 1961; 278: 1358.

21. Liew Z, Bach CC, Asarnow RF, Ritz B, Olsen J. Paracetamol use during pregnancy and attention and executive function in offspring at age 5 years. Int J Epidemiol 2016; 45 (6): 2009-2017.

22. Liew Z, Ritz B, Virk J, Arah OA, Olsen J. Prenatal use of acetaminophen and child IQ: A Danish cohort study. Epidemiology 2016; 27 (6): 912-8.

23. Liew Z, Ritz B, Virk J, Olsen J. Maternal use of acetaminophen during pregnancy and risk of autism spectrum disorders in childhood: A Danish national birth cohort study. Autism Res 2016; 9 (9): 951-8.

24. Rebordosa C, Kogevinas M, Sørensen HT, Olsen J. Pre-natal exposure to paracetamol and risk of wheezing and asthma in children: a birth cohort study. Int J Epidemiol 2008; 37 (3): 583-90.

25. Liew Z, Ritz B, Rebordosa C, Lee PC, Olsen J. Acetaminophen use during pregnancy, behavioral problems, and hyperkinetic disorders. JAMA Pediatr 2014; 168 (4): 313-20.

26. Carlsen E, Giwercman A, Keiding N, Skakkebaek NE. Evidence for decreasing quality of semen during past 50 years. $B M J$ 1992; 305 (6854): 609-13.

27. Levine H, Jørgensen N, Anderson MA, Mendiola J, Weksler-Derri D, Mindlis I, Pinotti R, Swan SH. Temporal trends in sperm count: a systematic review and meta-regression analysis. Human Reprod Update 2017 [Epub ahead of print]. 